\title{
PENGARUH INOKULASI BAKTERI Rhizobium japanicum TERHADAP PERTUMBUHAN KACANG KEDELAI (Glycine max L)
}

\author{
M. Pattipeilohy, Raymond A. B. Sopacua \\ 'Dosen Program Studi Pendidikan Biologi \\ Mahasiswa Program Studi Pendidikan Biologi
}

E-mail: ray_sopacua@yahoo.com

\begin{abstract}
Background: In Indonesia, soy is the third crop after rice and maize. Not only as a food ingredient, soybean (Glycine max L) also known as animal feed and industry.

Method: The materials used in this study are Rhizobin, seed soybeans, sugar, and ground. Research using a completely randomized design (CRD), which consists of one factor, ie the number of Rhizobium inoculation, with concentrations: $\mathrm{A} 0=$ Control, $\mathrm{A} 1=$ concentration of $3 \mathrm{~g}, \mathrm{~A} 2=$ Concentration $5 \mathrm{~g}$, and $\mathrm{A} 3=$ concentration of $7 \mathrm{~g}$. Each treatment was repeated three times. Data were analyzed using analysis of variance followed by honest significant difference test at significant level of $0.5 \%$ and $0.1 \%$.

Result: Delivery of bacterial inoculation treatments gave a significant influence on plant height, leaf number, and the number of soybean root nodules, obtained on treatment of Rhizobium inoculation A3 $=$ concentration of $7 \mathrm{~g} . T$ treatment of bacterial inoculation of soybeans increases the diameter of the rod, but no significant effect on stem diameter of soybean.

Conclusion: Bacteria Rhizobium inoculation japanicum significant effect on the growth of soybean plant, ie plant height, number of leaves and number of root nodules, but no significant effect on stem diameter. Concentration Inoculation of Rhizobium bacteria are the most influential on A3 concentrations $(7 \mathrm{~g})$, followed by concentration of $\mathrm{A} 2(5 \mathrm{~g})$, then the concentration of $\mathrm{A} 1(3 \mathrm{~g})$, and control (A0).
\end{abstract}

Keywords: inoculation, Rhizobium bacteria, Growth, and Soybeans.

\begin{abstract}
Abstrak
Latar Belakang: Di Indonesia, kedelai merupakan tanaman pangan ketiga setelah padi dan jagung. Tidak hanya sebagai bahan pangan, kedelai (Glycine max L) juga dikenal sebagai bahan pakan ternak dan industri.

Metode: Bahan yang digunakan adalah Rhizobin, benih kacang kedelai, gula pasir, dan tanah. Penelitian menggunakan Rancangan Acak Lengkap (RAL) yang terdiri dari satu faktor, yaitu banyaknya inokulasi Rhizobium, dengan konsentrasi: $A_{0}=$ Kontrol, $A_{1}=$ Konsentrasi $3 \mathrm{gr}, A_{2}=$ Konsentrasi $5 \mathrm{gr}$, dan $\mathrm{A}_{3}=$ Konsentrasi $7 \mathrm{gr}$. Masing-masing perlakuan diulang sebanyak 3 kali. Data yang diperoleh dianalisis menggunakan analisis varians dan dilanjutkan dengan uji beda nyata jujur pada taraf signifikan $0,5 \%$ dan $0,1 \%$.

Hasil: Pemberian perlakuan inokulasi bakteri memberikan pengaruh yang sangat nyata terhadap tinggi tanaman, jumlah daun, dan jumlah bintil akar kacang kedelai, yang diperoleh pada perlakuan $A_{3}=$ Konsentrasi inokulasi Rhizobium 7 gr. Perlakuan inokulasi bakteri meningkatkan diameter batang kacang kedelai, tetapi tidak memberikan pengaruh nyata terhadap diameter batang kacang kedelai.

Kesimpulan: Inokulasi Bakteri Rhizobium japanicum berpengaruh nyata terhadap pertumbuhan tanaman kacang kedelai, yaitu tinggi tanaman, jumlah daun dan jumlah bintil akar, namun tidak memberikan pengaruh nyata terhadap diameter batang. Konsentrasi Inokulasi Bakteri Rhizobium yang paling berpengaruh terdapat pada konsentrasi $A_{3}$ (7gr), disusul konsentrasi $A_{2}$ (5gr), selanjutnya konsentrasi $A_{1}(3 g r)$, dan kontrol $\left(A_{0}\right)$.
\end{abstract}

Kata Kunci: Inokulasi, Bakteri Rhizobium, Pertumbuhan, dan Kacang Kedelai. 


\section{PENDAHULUAN}

Kedelai merupakan salah satu tanaman sumber protein yang sangat berperan dalam kehidupan Manusia, terutama dalam menyediakan pangan. Di Indonesia, kedelai merupakan tanaman pangan ketiga setelah padi dan jagung. Tidak hanya sebagai bahan pangan, kedelai (Glycine max L) juga dikenal sebagai bahan pakan ternak dan industri (Adisarwanto dan Widyastuti, 2000). Walau begitu pentingnya tanaman ini, ternyata produksi kedelai di Indonesia masih sangat rendah, dilihat dari jumlah protein yang dihasilkan tiap hektar dimana hasil rata-rata 0,8 ton/ha, kedelai menghasilkan $225 \mathrm{~kg}$ protein sementara jagung dengan hasil 3,5 ton/ha hanya menghasilkan $225 \mathrm{~kg}$ protein (Suprapto,1995). Hal ini disebabkan karena belum menyebarnya pemakaian varietas unggul, serta cara bercocok tanam yang belum diperbaiki.

Adapun faktor-faktor yang mempengaruhi pertumbuhan kedelai bagi masyarakat khususnya petani seperti kekeringan, banjir hujan terlalu besar pada saat pertumbuhan dan perkembangan, serangan hama, penyakit dan persaingan dengan gulma. Adapula pandangan petani bahwa tanaman kedelai hanyalah merupakan tanaman sampingan, suatu persepsi seperti ini juga dapat merupakan salah satu faktor rendahnya tingkat teknologi budidaya tanaman kedelai selain itu, karena pemeliharaan kurang intensif sehingga pertumbuhan tanaman tersebut akan menurun (Sumarno, 1991).

Kedelai banyak mengandung nilai gizi seperti protein, lemak dan vitamin sehingga tidak mengherankan bila kedelai mendapat julukan "Gold from the soil" (emas yang muncul dari dalam tanah) selain itu, penggunaan kedelai sebagai bahan makanan oleh masyarkat seperti tahu kecap, tempe dan makanan lainnya oleh masyarakat dapat dimanfaatkan di bidang ekonomi khususnya pada pemasaran dalam negeri.

Berbeda dengan tanaman padi dan jagung tanaman kedelai pada umumnya tidak memberikan hasil secara menyolok bila diberikan pupuk urea, itu juga merupakan salah satu faktor lambatnya peningkatan produksi suatu kedelai. Namun dewasa ini, pengembangan tanaman kedelai (Glycine max L) di Indonesia terus dilakukan. Salah satu alternatif yang diambil adalah dengan menghadirkan varietas-varietas baru yang salah satunya adalah Dieng. Dari situlah dengan perkembangan ilmu pengetahuan yang semakin meluas dalam usaha untuk memperluas penanaman kedelai, adapun cara yang digunakan dalam proses ini yaitu Inokulasi Bakteri Rhizobium japanicum pada lahan yang baru di buka dengan $\mathrm{pH}$-nya rendah untuk itu agar kita dapat memperoleh hasil yang baik maka tanah bekas tanaman padi atau kacang tanah karena tanah tersebut sangat baik digunakan sebagai bahan inokulan selain itu, ada juga teknik inokulasi buatan dengan memanfaatkan bakteri rhizobium pada benih. (Suprapto, 1995).

Pada umumnya bakteri itu ada yang bersifat patogen dan ada pula yang menguntungkan khususnya pada bakteri Rhizobium yang hidupnya bersimbiosis dengan akar kacang polong-polongan dimana bakteri tersebut sangat berperan penting dalam proses pertumbuhan tanaman kacang kedelai karena kacang kedelai dalam proses pertumbuhannya sangat membutuhkan Nitrogen (N2) maka yang berfungsi untuk mengikat nitrogen bebas di udara adalah bakteri Rhizobium japanicum. Tujuan penelitian ini adalah adakah pengaruh Inokulasi Bakteri Rhizobium japanicum Terhadap Pertumbuhan Kacang Kedelai (Glycine max L) dan konsentrasi Inokulasi Bakteri Rhizobium japanicum manakah yang paling berpengaruh terhadap Terhadap Pertumbuhan Kacang Kedelai.

\section{METODE}

Penelitian ini dilakukan pada bulan Agustus sampai September 2010, dilokasi Desa Waipirit Kecamatan Kairatu Kabupaten Seram Bagian Barat, menggunakan Rancangan Acak Lengkap (RAL) yang terdiri dari 1 faktor, yaitu banyaknya inokulasi Rhizobium, dengan 4 perlakuan dan 3 ulangan. Adapun perlakuan inokulasi Rhizobium sebagai berikut:

$A_{0}=$ Kontrol $/$ tanpa

inokulasi

Bakteri Rhizobium
$\mathrm{A}_{1}=$ Konsentrasi $3 \mathrm{gr}$
$\mathrm{A}_{2}=$ Konsentrasi $5 \mathrm{gr}$
$A_{3}=$ Konsentrasi $7 \mathrm{gr}$. 
Parameter yang diamati dalam penelitian ini adalah: Pertumbuhan tanaman kacang kedelai yang mencakup tinggi tanaman, jumlah daun, diameter batang, dan jumlah bintil akar. Kegiatan operasional yang dilakukan mencakup tahap persiapan alat dan bahan yang digunakan dalam proses, pensterilisasian tanah yang digunakan untuk media penanaman sebelumnya dengan menggunakan oven. Tahap Inokulasi yaitu benih kedelai dibasahi dengan air sehingga menjadi lembab. Kemudian ampurkan inokulan buatan pada benih kedelai dengan konsentrasi yang telah ditentukan yaitu, $3 \mathrm{gr}$, $5 \mathrm{gr}$ dan $7 \mathrm{gr}$. Untuk membantu melekatnya bakteri Rhizobium ke benih ditambahkan gula untuk tiap perlakuan adalah $1 \mathrm{gr}$ Kemudian percampuran dilakukan secara merata dan di tempat yang teduh. Kemudian angin-anginkan benih kedelai yang telah dicampur dengan inokulan selama 15 menit. Tahap selanjutnya penenanaman benih dengan menggunakan media tanam yaitu tanah Andosol di polybag. Data yang diperoleh dianalisis mengunakan Analisis sidik ragam (Analisis Varians)

\section{HASIL DAN PEMBAHASAN}

Hasil analisis sidik ragam menunjukan bahwa, perlakuan inokulasi Rhizobium memberikan pengaruh yang sangat nyata terhadap tinggi tanaman, jumlah daun, dan jumlah bintil akar kacang kedelai. Hasil Analisis Uji BNT Rata-rata Tinggi Tanaman kacang kedelai $(\mathrm{cm})$ pada minggu ke-1 sampai minggu ke-4 dapat dilihat pada tabel 1.

\section{Tabel 1. Hasil Uji BNT Rata-rata Tinggi Tanaman Kacang Kedelai (cm) Pada Minggu Ke- 1 Sampai Minggu Ke-4.}

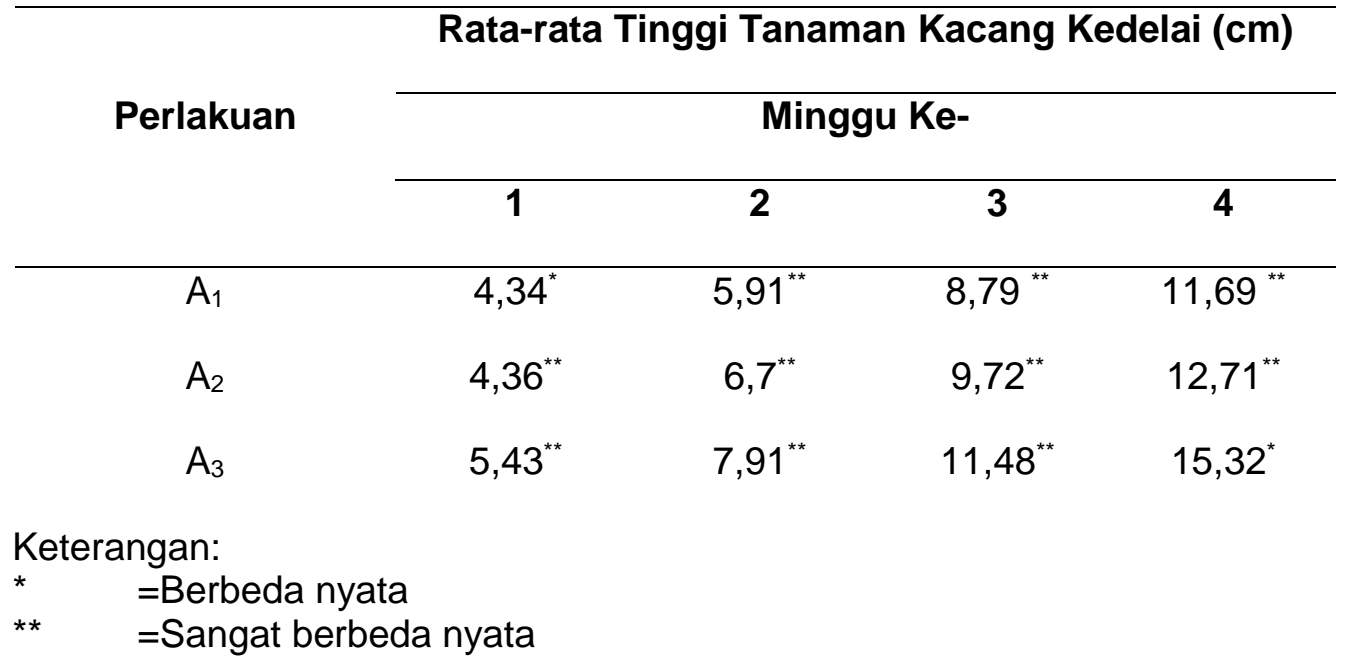

Hasil analisi sidik ragam menunjukan bahwa, perlakuan inokulasi Rhizobium memberikan pengaruh yang sangat nyata terhadap tinggi tanaman dan jumlah daun kacang kedelai, dari minggu ke-1 sampai minggu ke-4, dan jumlah bintil akar kacang kedelai. Hasil Analisis Uji BNT Rata-rata Jumlah Daun Kacang Kedelai pada minggu ke-1 sampai minggu ke-4 dapat dilihat pada tabel 2. 
Tabel 2. Hasil Uji BNT Rata-rata Jumlah Daun Kacang Kedelai pada minggu Ke-1 Sampai Minggu Ke-4.

\begin{tabular}{|c|c|c|c|c|}
\hline \multirow{3}{*}{ Perlakuan } & \multicolumn{4}{|c|}{ Rata-rata Jumlah Daun Kacang Kedelai } \\
\hline & \multicolumn{4}{|c|}{ Minggu Ke- } \\
\hline & 1 & 2 & 3 & 4 \\
\hline$A_{1}$ & $2,33^{* *}$ & $3,93^{\mathrm{TN}}$ & $6,2^{* \star}$ & $8,73^{\star *}$ \\
\hline $\mathrm{A}_{2}$ & $3,07^{* *}$ & $4,93^{* *}$ & $7,17^{\star \star}$ & $9,53^{* *}$ \\
\hline$A_{3}$ & $3,67^{\star *}$ & $5,67^{\star *}$ & $8,2^{* *}$ & $10,8^{* *}$ \\
\hline $\begin{array}{l}=\text { Tidak ber } \\
=\text { Sangat be }\end{array}$ & & & & \\
\hline
\end{tabular}

Hasil analisi sidik ragam menunjukan bahwa, perlakuan inokulasi Rhizobium memberikan pengaruh yang sangat nyata terhadap jumlah daun kacang kedelai, dari minggu ke-1 sampai minggu ke-4. Meskipun, pada mingu ke-2 pada perlakuan A1 tidak memberikan perbedaan nyata. Hasil Analisis Uji BNT rata-rata diameter batang kacang kedelai pada minggu ke-1 sampai minggu ke-4 dapat dilihat pada tabel 3 .

\section{Tabel 3. Hasil Uji BNT Rata-rata Diameter Batang Kacang Kedelai Pada Minggu Ke-1 Sampai Minggu Ke-4.}

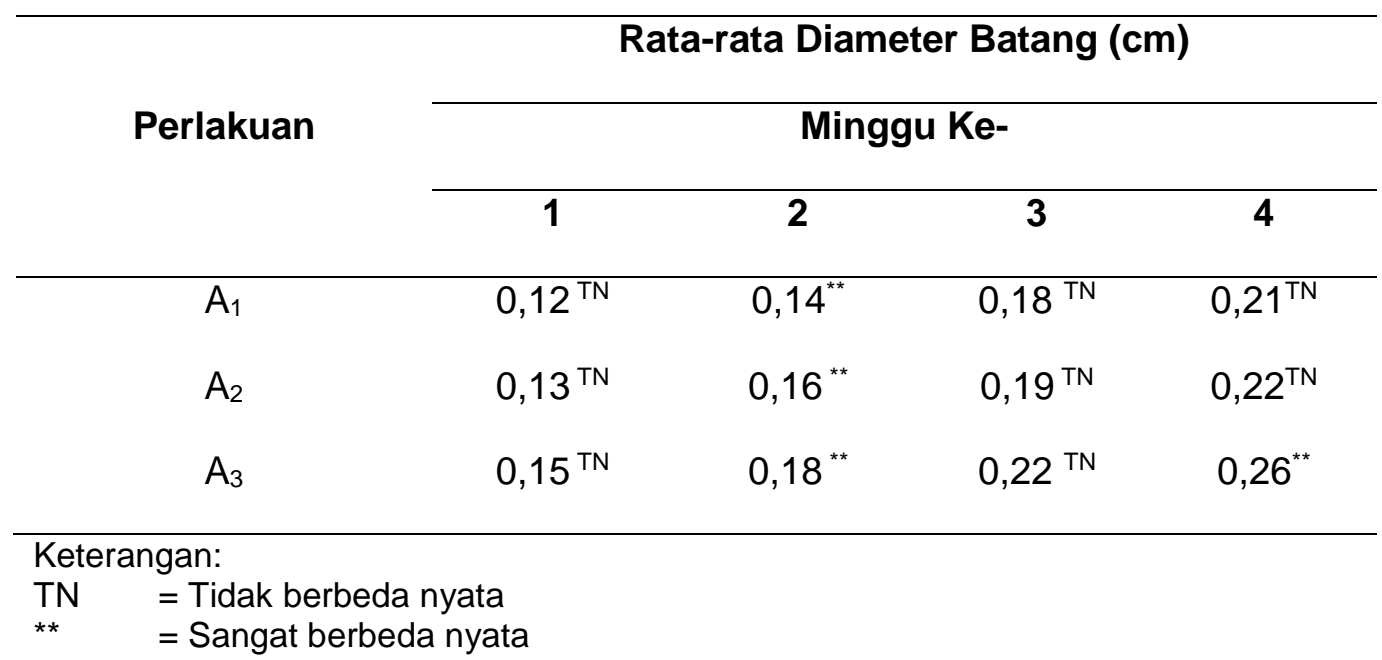

Hasil analisi sidik ragam menunjukan bahwa, perlakuan inokulasi Rhizobium tidak memberikan pengaruh nyata terhadap diameter batang kacang kedelai, pada minggu ke-1, minggu ke-2 dan minggu ke-4.
Meskipun, pada mingu ke-2 memberikan pengaruh yang sangat nyata. Hasil Analisis Uji BNT rata-rata jumlah bintil akar kacang kedelai dapat dilihat pada tabel 4 . 
Tabel 4. Hasil Uji BNT Rata-rata Jumlah Bintil Akar Kacang Kedelai pada minggu Ke-1 Sampai Minggu Ke-4.

\begin{tabular}{cc}
\hline & $\begin{array}{c}\text { Rata-rata Jumlah } \\
\text { Perlakuan }\end{array}$ \\
\cline { 2 - 2 } & Bintil Akar \\
\hline A1 & $7,6^{* *}$ \\
A2 & $9,07^{* *}$ \\
A3 & $11^{* *}$ \\
\hline
\end{tabular}

Keterangan:

${ }^{* *}=$ Sangat berbeda nyata

Hasil analisis sidik ragam menunjukan bahwa, perlakuan inokulasi Rhizobium memberikan pengaruh yang sangat nyata terhadap jumlah bintil akar kacang kedelai.

Hasil penelitian menunjukan bahwa, perlakuan inokulasi bakteri memberikan pengaruh yang sangat nyata terhadap tinggi tanaman, jumlah daun, dan jumlah bintil akar kacang kedelai. Ini disebabkan, karena Inokulasi Rhizobium membentuk bintil akar pada pada tanaman kacang kedelai, sehingga efektif dalam penembatan $\mathrm{N}_{2}$ udara (Purwanti, 1997). Lazuardi, dkk (2005) menjelaskan, Rhizobium adalah salah satu jenis bakteri yang dapat bersimbiosis mutualisme dengan tanaman polong (Leguminoceae) dengan cara membentuk bintil pada tanaman polong. Selanjutnya, Adisarwanto dan wudianto mengungkapkan, Dalam proses pertumbuhannya, kedelai sangat memerlukan nitrogen dalam jumlah yang cukup. Seperti yang diketahui, unsur Nitrogen dapat diserap tanaman langsung melalui sistem perakaran tanaman dan juga dapat diserap lewat fiksasi $\mathrm{N}_{2}$ yang dilakukan oleh bakteri Rhizobium yang bersimbiosis dengan tanaman kedelai. Ini sesuai dengan penjelasan Adijaya, dkk (2010), Nitrogen yang diperlukan tanaman kedelai bersumber dari dalam tanah dan juga dari atmosfir. Nitrogen yang berasal dari atmosfir diserap tanaman kedelai melalui simbiosis dengan bakteri Rhizobium. Bakteri ini membentuk bintil akar (nodul) pada akar tanaman kedelai, dan lewat bintil akar inilah bakteri Rhizobium melakukan penyematan/memfiksasi $\mathrm{N}_{2}$ dari udara sehingga dapat digunakan tanaman (Vest et al., 1976 dalam Purwanti, 1997). Hasil fiksasi nitrogen ini digunakan untuk memenuhi kebutuhan $\mathrm{N}$ yang diperlukan oleh tanaman kedelai. Selain itu, rhizobium dapat mempengaruhi pertumbuhan dan perkembangan tanaman dengan merubah status secara fisiologis, dan morfologis dari akar yang diinokulasi (Noel et al., 1996; Yanni et al., 1997; Biswas, 2000 dalam Anas dan Nigsih, 2004), seperti pernanjangan akar (Arshad dan Frankenberger, 1993; Kumar dan Narula, 1999 dalam Anas dan Nigsih, 2004) dan perkembangana akar lateral, sehingga Bermanfaat dalam memperbaiki serapan hara.

Nitrogen sangat diperlukan tanaman dalam pembentukan senyawa asam amino yang penting dalam sintesis protein untuk penyusunan protoplasma sel. Selama pertumbuhan tanaman. Menurut Copeland (1976) dalam Purwanti (1997), Nitrogen merupakan penyusun senyawa penting seperti purin, pirimidin, prifirin yang diperlukan untuk pertumbuhan tanaman. Ini didukung oleh Tohari (2010),

Pertumbuhan tinggi tanaman kacang kedelai terjadi didalam meristem apikal. Meristem ujung/meristem apikal menghasilkan sel-sel baru di ujung akar atau batang, mengakibatkan tumbuhan bertambah tinggi atau panjang (Gardner dkk. 1991).

Pertumbuhan daun kacang kedelai diawali dengan sel-sel tertentu didalam kubah ujung, yang membelah (menjadi 
merismatik). Melalui ini, keluar tunas-tunas daun (Gardner dkk. 1991).

Bintil akar terbentuk mulai dari masuknya bakteri kedalam rambut-rambut akar yang mash muda dengan jalan mencari bagian-bagian yang lunak, bagian yang mudah dimasuki, terutama pada jaringan kulit luar yang telah rusak. Namun ada kalanya bakteri dapat menembus jaringan kulit luar yang masih utuh. Setelah berada dalam akar, bakteri kemudian menginfeksi akar tanaman, dan membentuk bintil-bintil akar (Silalahi, 2009). Jumlah bintil akar (leghemoglobin) pada akar, memiliki hubungan langsung dengan jumlah nitrogen yang difiksasi. Semakin banyak $\mathrm{N}$ yang difiksasi, maka akan semakin banyak bintil akar (leghemoglobin) yang terbentuk dan meningkatnkan simbiose bakteri (Rahmati, 2005; Adijaya, dkk, 2010).

Meskipun, perlakuan inokulasi bakteri Rhizobium dapat meningkatkan pembesaran pada diameter batang kacang kedelai, namun berdasarkan hasil analisis, ternyata perlakuan inokulasi bakteri Rhizobium tidak memberikan pengaruh yang nyata terhadap diameter batang kacang kedelai. Ini munglin disebabkan, karena bentuk batang kacang kedelai itu sendiri. Silalahi (2009) menjelaskan, Kedelai memiliki batang berbentuk semak. Dengan bentuk batang semak tersebut, memungkinkan peningkatan pembesaran pada tiap batang tidak akan berbeda jauh antara satu dan lainnya.

\section{KESIMPULAN}

Inokulasi Bakteri Rhizobium japanicum memberikan pengaruh nyata terhadap pertumbuhan tanaman kacang kedelai, yaitu tinggi tanaman, jumlah daun dan jumlah bintil akar. Namun, tidak memberikan pengaruh nyata terhadap diameter batang. Konsentrasi Inokulasi Bakteri Rhizobium yang paling berpengaruh terdapat pada konsentrasi $A_{3}$ (7 gr), disusul konsentrasi $A_{2}$ (5 gr), selanjutnya Konsentrasi $A_{1}$ ( $\left.3 \mathrm{gr}\right)$, dan Kontrol $\left(A_{0}\right)$. Disarankan untuk hasil yang lebih baik, sebaiknya menggunakan inokulasi Rhizobium japanicum dengan konsentrasi yang ditentukan yaitu 5-7 gr. Disamping penelitian lain lebih lanjut dengan menggunakan parameter yang lain.

\section{DAFTAR PUSTAKA}

AAK. 1991. Kedelai, Penerbit Kanisius, Jogjakarta halaman 7-9

Anonym 1973. Lahan kacang-kacangan. Lembaga Pusat Pertanian Bogor.

Adisarwanto, T dan Widyastuti, Y. E. 2000. Meningkatkan Produksi Kedelai di Lahan Kering, Sawah, dan Pasang Surut. Penebar Swadaya: Jakarta.

Adisarwanto, T dan Wudianto, R. 2008. Meningkatkan Hasil Panen Kedelai di Lahan Sawah-Kering-Pasang Surut, Penerbit Penebar Swadaya; Jakarta.

Bidan, Akademi, 2009. Mikrobiologi. (http://akademibidan.blogspot.com/200 9/03/mikrobiologi. html) Diperoleh tanggal 25 Oktober 2009 pukul 01:04:57

Danamik, M. 2000. Pemanfaatan Bakteri Rhizobium Pada Tanaman Kedelai di lahan lebar Hasil Penelitian Tamu alara 1999/2000, Balai Penelitian Tanaman Pangan. Lahan rawa banjar buru.

Gurungeblog, 2008. Bakteri-Ciri-ciri, Struktur, Perkembangbiakan, Bentuk dan

Manfaatnya.(http://gurungeblog.wordpr ess.com/2008/11/17/bakteri-ciri-ciristruktur-perkembangbiakan-bentukdan-manfaatnya/). Diperoleh tanggal 17 Desember 2009 pukul 23:38:54

Hanafiah, K. A. 2005. Rancangan Percobaan Teori dan Aplikasi. Rayagrafindo Persada: Jakarta.

Hardjo, 1989.Pengaruh Inokulasi Bakteri Rhizobium japanicum terhadap pertumbuhan dan hasil kedelai (Glycine max, L, Meriil) yang di tanam pada tanah berpasir.

Hasbi, Hudaini, 2009. Fiksasi Nitrogen oleh Bakteri.

(http://bisnisonline.web.id/_a1/ind.ico) Diperoleh tanggal 19 Desember 2009 pukul 02:14:52

Irianto, Koes. 2007. Mikrobiologi Mengurah Dunia Organisme jilid 1, Penerbit CV. Yrama Widya; Bandung.

Jutono, 1981. Fiksasi Nitrogen $\left(\mathrm{N}_{2}\right)$ Pada leguminosae dalam pertanian (suatu pedoman untuk Inokulasi). Lab Mikrobiologi Fakultas Pertanian, Universitas Gajah Mada, Jogyakarta. 
Prabowo Yudi A. 2005, Teknik Budidaya Kedelai, Penerbit Penebar Swadaya: Jakarta

Sumarno, N. dan W. Gunawan. 1987, Pengaruh pengelolaan tanah dan populasi tanaman terhadap pertumbuhan kedelai, laporan kemajuan penelitian seri argon kacang-kacangan, LP3 Bogor.

Waluyo, 2009.Teknik dan Metode Dasar Mikrobiologi, Penerbit Penebar Swadaya: Jakarta.

Purwanti, S. 1997. Usaha Meningkatkan Kuantitas dan Kualitas Hasil Benih Kacang Hijau (Vigna radiata (L.) Willczek) Dengan Inokulasi Rhizobium dan Pupuk TSP.

Anas, I dan Ningsih, R. D. 2004. Tanggap Tanaman Kedelai terhadap Inokulasi Rhizobium dan Asam Indol Asetat (IAA) pada Ultisol Darmaga. (Online). (http://iirc.ipb.ac.id/jspui/bitstream/123 456789/35507/1/ 2.5.pdf).

Rahmati, S. 2005. Pemanfaatan Biofertilizer Pada Pertanian Organik. (Online) (http: //digilib.unnes.ac.id/gsdl/collect/skripsi /index/assoc/HASHcca0. dir/doc.pdf)
Silalahi, H. 2009. Pengaruh Inokulasi Rhizobium dan Pupuk Fosfat Terhadap Pertumbuhan dan Produksi kedelai (Glycine max L. Merril).

Suharjo, U. K. J. 2001. Efektivitas Nodulasi Rhizobium japonicum Pada Kedelai yang Tumbuh Di Tanah Sisa Inokulasi dan Tanah Inokulasi Tambahan.

Tohari, Y. 2010. Unsur Hara dan Fungsinya. (Online). Diakses 28 Mei 2010 00:34:22 GMT.

Adijaya, I. N, Suratmi, P dan Mahaputra, K. Aplikasi Pemberian Legin (Rhizobium) Pada Uji Beberapa Varietas Kedelai Di Lahan Kering

Lazuardi, dkk. 2005. Rhizobium Sebagai Pupuk Hayati pada Tanaman Leguminoceae.

Kastono, D. 2005. Tanggapan Pertumbuhan dan Hasil Kedelai Hitam Terhadap Penggunaan Pupuk Organik dan Biopestisida Gulma Siam (Chromolaena odorata). (Online). 02 Januari 2010 14:09:21 GMT.

Gardner, F. P., Pearce, R. B., dan Mitchell, R. L. 1991. Fisiologi Tanaman Budidaya Universitas Indonesia (UIPress): Jakarta. 